\title{
Study on the Research and Practise of Experiment Teaching in Fire Combustion Science Course
}

\author{
Yuanyuan Wang \\ Kunming Command School of Public Security and Fire \\ Fighting Army \\ Kunming, China \\ 1009541492@qq.com
}

\begin{abstract}
It is a good way of develop experiment teaching in fire combustion course and train students the ability to analyze and solve the preventing and control of fire and explosion accident to let graduate satisfy the practical request of fire job. This paper unfolds research and practice for experiment teaching in fire combustion course of fire school.
\end{abstract}

Keywords-fire combustion science course; experiment teaching;reaearch;practice

\section{INTRODUCTION}

Fire combustion course is an important professional basic course of fire education. It mainly studies the fire occurrence, development and extinction basic laws, and it provides theoretical guidance for fire protection and firefighting work.

Kunming fire command school is the only school to train basic fire commander in the nation scope. The students must learn fire combustion course to master the basic characteristics of flammable material combustion or explosion and the knowledge of fire prevention. Their ability can be improved to analyze and solve a fire or explosion accident prevention and so on.

\section{THE NECESSITY OF TEACHING CURRICULUM}

Experimental teaching is the process of testing knowledge point and deepening the memory. At the same time, it also strengthens the students' practical ability and improves theirs experimental quality. Therefore, the experimental class plays a decisive role in the teaching activities. Fire combustion science course is a subject based on experiment; the experiment is an important part of the curriculum teaching. The experiment can train students train students the ability to analyze fire or explosion accident prevention. It has important significance to change the significance to change the learning method and cultivate the the life-long learning ability

\section{THE EXPERIMENT ROLE}

\section{A.The experiment can improve the students' learning interest Selecting a Template}

Interest is the source of knowledge and the power of thinking. The experiment has the myriad phenomena to arouse the learning interest effective means. Interest is the source of knowledge and the power of thinking. The experiment has the myriad phenomena to arouse the learning interest effective means. The experiment phenomena attract students in the process of experiment. For example, the teacher puts the methanol, ethanol, the acetone and the benzene into the evaporation pan, and then the teacher ignites the reagents to let the students to observe and understand the flame characteristics of combustible material.

The flames of methanol and ethanol have smoke. The flame of acetone and benzene is explicit. Then a small amount of methanol are added respectively into the five pans and light, the sodium chloride, calcium carbonate, barium nitrate, copper nitrate and strontium nitrate powder are thrown into the flame. Then the flames of methanol change into yellow flame bolarious flame, green flame, blue flame and red flame. The students are curious with colour flame in the experiment. The students have a strong interest in learning and enhance the perceptual knowledge of the materials combustion characteristics through this experiment. The experiment phenomena can show and verify the theoretical knowledge on the books to improve the teaching effect. The fire combustion science course sets up the experiments in the following table.

\begin{tabular}{lc} 
TABLE 1 THE EXPERIMENTS IN THE FIRE COMBUSTION SCIENCE COURSE \\
\hline The experiment name & Class hours \\
\hline The material combustion conditions & Two \\
The characteristics flame & Two \\
The flame retardant property & Two \\
The flash point and ignition of the flammable liquid & Two \\
The combustion of solid objects & Two \\
& \\
\hline
\end{tabular}

\section{$B$. The experiment can content the teaching with the actual fire work}

It is actually need for fire combustion science teaching to combine with the fire work. Experimental teaching is a good 
way to combine the theoretical knowledge with practical fire control work. For example, the combustion phenomena enable students to deepen the understanding of combustion conditions in the combustion condition experiment.

The experiments lay good theoretical foundation for firefighting work, because fire protection and firefighting contact closely with the combustion condition. In this experiment, students can visually see the gasoline; kerosene and diesel oil concentrations influence the combustion phenomena. The experiment phenomena explain that the combustion must meet three basic conditions and the four sufficient conditions. The experiments provide the most effective help for fire control work. In addition, the students can observed the flame characteristics in the experiments and grasp accurately the flame temperature influence. The experiments phenomena can help the students take appropriate measures at fire scene. The abstract textbook content can be explained well by experiments, so they play very good teaching effect to prevent the flame expansion.

\section{The spirit of cooperation and harmony can be cultured}

In the modern social life and scientific work, the communication and cooperation between individuals and groups are very important. The communication and cooperation ability are very necessary when the graduates engage in the fire control work. The complexity and diversity also need the division of labor and cooperation among the students. The experimental materials, experimental operation and the experimental conclusion need to cooperate. For example in the flammable liquid flash point and ignition experiment, each group of students should be a clear division of labor. Some students heat the diesel oil, some students observe temperature changes. The experiment laid the foundation for cooperation and coordination to train the students the fire spirit.

\section{THE EXPERIMENT TEACHING STATUS}

At present, there are five experiments in fire combustion science course, experiment teaching, we gain some achievements, but the experiment teaching also exposed some problems.

\section{A. The learning foundations of students are weak}

The teacher must first master students' original perceiving structure and teaching accords with students' perceiving ability to let students attain better development on the original basis. The students' basis of our school is irregular most of students learn arts before joining the army. So their basis is very weak and they generally feel difficult after learning fire combustion science in fire school. In order to fully grasp the actual degree of the students and the cultural foundation, we investigate one hundred and forty-two students of new enrollment in 2014. On the whole, the students' cultural foundation is very bad and learning ability is not strong.

\section{B.The problems in the experiment teaching of fire combustion science course}

The students ignored the experiment classes. Quite a few students do not attach importance to the chemical experi- ment; they only cope with the teacher. The students do not consider whether operations are standard and the experiment dates are proper.

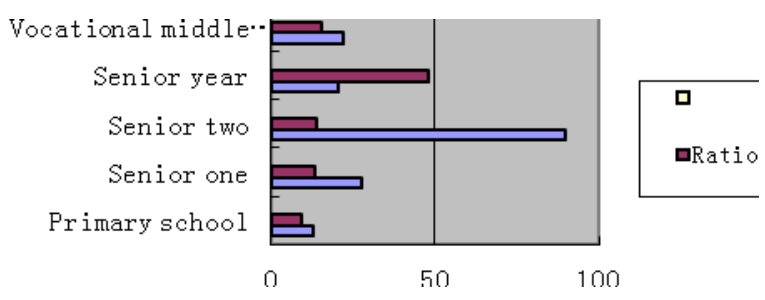

Fig.1. Educational condition statistics

On the other hand, some students think that the course has little contact with the fire work, so they will not pay attention to the experiment teaching. The fire combustion science experiment class has become almost leisure class.

The experiment ability of students is poor. For example, in the experiment of flammable liquid flash point and ignition, the students design experiment by themselves. Some students do not put the thermometer into the mixed solution of ethanol and water, some students do not put the thermometer vertically into the central position of the mixed solution, and other students do not know how to determine the proportion of mixture and how to achieve the right mix proportion.

The experimental procedures of students are not correct. In the flammable liquid flash point measure

Experiment, the students are eager to heat porcelain crucible by the alcohol burner before vertically fixing the thermometer into the porcelain crucible.

The basic skills of experiment operation are poor. The close cooperation of the students is not in place. The students extinguish the alcohol lamp flame wrongly.

The students observe and interpret experiment phenomena defectively. They observe experiments carelessly, so the experiment descriptions often are not clear and complete. The experimental phenomena should be expressed completely, but a large number student often describes only the experiment phenomena partly. It is difficult for the students to write experiment reports accurately.

The experiment reports reflect the whole process of the chemical experiment. Many students often write experiment report carelessly, some students focus on appearance, some students do not write emphasis, and some students do not respect the objective facts.

\section{STUDY ON IMPROVING THE EXPERIMENT TEACHING EFFECT}

\section{A. The teacher should renew the teaching ideas}

The teacher should change the past experiment teaching pattern. The past experiment teaching only pays attention to 
verify the theory knowledge. Therefore, the teacher should correct the bad learning habits and cultivate the students' independence learning ability. The experiment teachings finally become the practice activities of collecting and processing information.

\section{B.The teacher should emphase the experiment teaching purpose, requirement and meaning}

The teacher should emphasize the experiment purpose to arouse the students' thirst for knowledge before the class. The students' attention on the experiment can be aroused by combing with the book to explain the experiments position and the function. Therefore, the teacher should indicate the experiment purpose and meaning of experimental teaching before the class.

\section{C.Students' basic operation ability can be strengthened}

In the experiment processes, the teacher should supervise the students to let them set up the correct experiment attitude and cultivate the good experiment quality. The teacher also explains the correct operation and the harm of violation the operating so that the students operate accurately and the unnecessary waste can be reduced.

\section{D.The teacher should design experiments as much as possible to guide the students to explore actively}

The teacher should train the students to think actively and explore the new knowledge. Therefore, the teacher should set up the experiments as much as possible according to the actual need of fire work. For example, the student may design the experiment procedure after testing the flash point of the diesel oil. The students grasp the theoretical knowledge of flash point and train the ability of understanding the flash point of other flammable liquid through the designed experiment. The experiment teaching way can enhance the student's interest in the experiment and achieved the good teaching effect.

\section{E.The use of new experiment teaching methods and means}

The teacher should make full use of modern experiment teaching methods such as the video and the multimedia means. This teaching way attracts the students to make students gain spiritual satisfaction and produce higher levels desire. The students can fully mobilize the enthusiasm to use the theory knowledge of combustion and explosion to analyze and solve the practical fire problems.

\section{REFERENCE}

[1] Jiatai, Zhu. 2002. The artistic theory of chemistry teaching. Nanning: Guangxi education Press.

[2] Youli, Zhao.2005. Building favourable teaching atmosphere in classroom. The Form of contomparary education. (6):59-60.

[3] Jinzhou, Zheng. 2000 .The general theory of education. Shanghai:East China normal university press.

[4] Lan, Ye, etc. 2001, The new discussion of teachers role and development. Beijing: Education science press.

[5] Hua, Zhang. 2000.The curriculum and teaching theory. Shanghai: education press. 